\title{
Statistical study regarding the interest of the dentists related to the use of dental ceramic veeners
}

\author{
Studiu statistic privind gradul de interes al medicilor dentişti legat de utilizarea \\ tehnicilor de faţetare ceramică
}

\author{
C. Sindila, Anamaria Florescu, A. Burcea, Cornelia Bîcleşanu \\ Disciplina Odontoterapie, Facultatea de Medicină Dentară, Universitatea „Titu Maiorescu“, Bucureşti
}

\begin{abstract}
Minimally invasive therapy represents the actual therapeutic trend used in all dental specialties. In the last decades, the direct veneer restoration technique has been on an ascending trend, linked to the will of achieving esthetic restoration with minimally dental tissue sacrifice. The purpose of this study is to evaluate practitioners rate of interest regarding minimally invasive techniques.

Material and method. The study has been conducted based on an electronic survey send to a number of 180 dentists from Bucharest.

Results and discussions. The response rate was $69.4 \%$. Most of the respondents $97(78 \%)$ know the minim invasive therapie procedures, but $28(22 \%)$ does not apply them in the daily practice. The study showed that direct restoration is the most preferred technique $30 \%, 51 \%$ choose to prepare the vestibular surface limited to enamel only and $47 \%$ use lithium disilicate based ceramic. Almost $90 \%$ of the patients have declared themselves satisfied regarding estethics, without revealing significant differences concerning the failure of ceramic veneers versus the type of used ceramics, or the level of tooth preparation and used ceramics. The results revealed a correlation between the patients levels of satisfaction and the preparation design $(r=0.015)$.

Conclusions. Developing proper diagnostic analyzes correlated with operator's experience and strictly follow the therapeutic protocol can determine an increase in the lifespan of ceramic veneers.
\end{abstract}

Keywords: ceramics veneers, questionnaire, degree of interest of dentists

\section{REZUMAT}

Terapia minimum invazivă reprezintă tendinţa terapeutică actuală aplicată în toate specialităţile dentare. Tehnica de fateţare cu materiale ceramice a avut în ultimele decenii un trend ascendent, legat de dorinţa de aplicare a unor refaceri estetice cu minimum de sacrificiu de substanţă dură dentară. Scopul acestui studiu este de a evalua gradul de interes al practicienilor legat de tehnicile minimum invazive.

Material şi metodă. Studiul s-a efectuat pe baza unui chestionar care a fost trimis electronic unui număr de 180 medici dentişti din Bucureşti.

Rezultate şi discuţii. Rata de răspuns a fost de 69,4\%. Majoritatea repondenţilor 97 (78\%) cunosc procedurile TMI, dar $28(22 \%)$ nu le folosesc în practica curentă. Studiul a arătat că faţetarea directă este tehnica preferată $(30 \%), 51 \%$ aplică prepararea la nivelul feţei vestibulare la nivelul smalţului, $47 \%$ dintre repondenţi folosesc ceramică pe bază de litiu disilicat. Aproape $90 \%$ dintre pacienţi s-au declarat satisfăcuţi din punct de vedere estetic, fără existenţa diferenţei semnificative între apariţia eşecurilor faţetelor ceramice vs. tipul de ceramică utilizat, nivelul de preparaţie a structurilor dentare sau tipul de ceramică utilizat. Rezultatele au arătat că există corelaţie între gradul de satisfacţie al pacienţilor şi designul preparaţiei $(r=0,015)$.

Concluzii. Realizarea unor analize diagnostice corecte asociate cu experienţa operatorului şi respectarea unui protocol terapeutic strict pot determina creşterea ratei de supravieţuire a faţetelor realizate din materiale ceramice.

Cuvinte cheie: faţete ceramice, chestionar, grad de interes

\section{INTRODUCERE}

Plecând de la conceptul terapiei minimum invazive, se utilizează în practica dentară o serie de me- tode terapeutice precum faţetarea directă sau indirectă, tunelizarea, preparaţia atraumatică etc. În prezent, unii clinicieni aplică în mod curent aceste tehnici, dar există şi o altă categorie care nu are 
competenţele necesare pentru aplicarea acestor protocoale minimum invazive.

Scopul studiului a fost de a evalua interesul şi nevoia medicilor din domeniul medicinei dentare pentru aplicarea în activitatea curentă a tehnicilor minimum invazive, cu aplecare specială asupra tehnicii de fateţare indirectă.

Obiectivele studiului au fost următoarele:

1. Determinarea interesului medicilor dentişti pentru tratamentele minimum invazive;

2. Determinarea metodelor de tratament minimum invaziv utilizate în cabinetele dentare;

3. Determinarea interesului pentru perfecţionarea cunoştiinţelor în acest domeniu;

4. Determinarea interesului pentru dotarea cabinetului cu materiale şi aparatură utilă intervenţiilor minimum invazive.

5. Determinarea unor specificaţii clinice caracteristice ale fațetelor indirecte (preparare, materiale, eşecuri, rată supravieţuire) cumulate din experienţa clinică personală.

6. Stabilirea corelaţiei statistice între rata de eşec/grad supravieţuire faţete cu nivelul de pregătire, experienţa, mod de preparare dinţi, material ceramic etc.

\section{MATERIAL ŞI METODĂ}

Studiul s-a efectuat pe baza unui chestionar care a fost trimis electronic unui număr de 180 medici dentişti din Bucureşti. Participarea a fost voluntară şi toate informaţiile au fost confidenţiale şi anonime.

Chestionarul conţine un număr de 18 întrebări, într-o primă secţiune, întrebări legate de date demografice şi profesionale, cum ar fi vârstă, sex, vechime în activitate, nivel profesional. În secţiunea II sunt formulate întrebări referitoare la modul şi ritmicitatea de aplicare a tehnicilor minimum invazive (TMI), cu o subsecţiune specială care se axează pe aspecte legate de faţetarea indirectă.

Pentru analiza statistică s-a folosit coeficientul de corelaţie Spearman (corelaţia Spearman, pe scurt, marcată de simbolul R) care este o măsură nonparametrică a forţei şi a direcţiei de asociere care există între două variabile măsurate la cel puțin o scală ordinală.

\section{REZULTATE}

Rata de răspuns a fost de $69,4 \%$, ceea ce reprezintă returnarea a 125 de chestionare.
Din totalul medicilor participanţi la studiu, 87 $(70 \%)$ au fost de sex feminin, 38 (30\%) de sex masculin (Fig. 1).

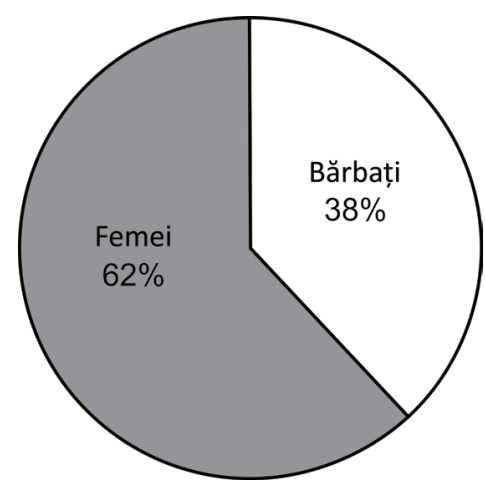

FIGURA 1. Repartiția lot după sexe

Lotul a fost împărţit pe categorii de vârstă şi s-a constatat că grupa de vârstă 26-36 ani a fost cel mai bine reprezentată (37), iar grupa 57-66 ani - cea mai redusă (15\%) (Fig. 2).

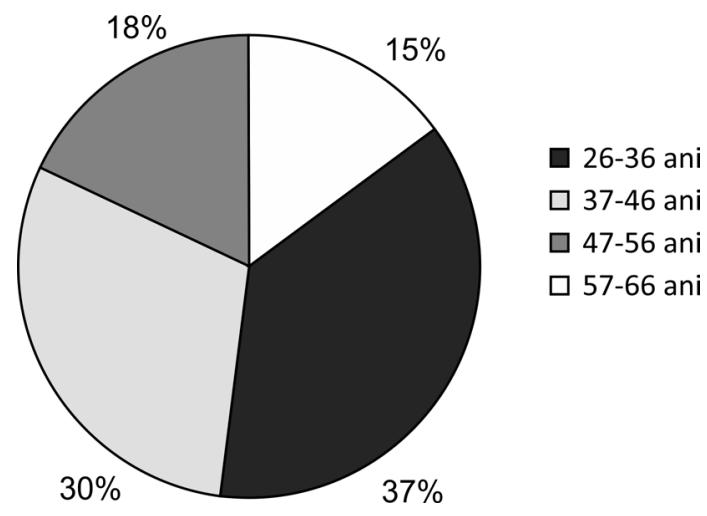

FIGURA 2. Repartiția pe grupe de vârstă a repondenților

În continuare, s-a determinat repartiţia repondenţilor în funcţie de experienţa lor în domeniul practicii dentare. $42 \%$ dintre ei au o experienţă de 4-7 ani şi $29 \%$ au mai mult de 10 ani de la terminarea studiilor (Fig. 3).

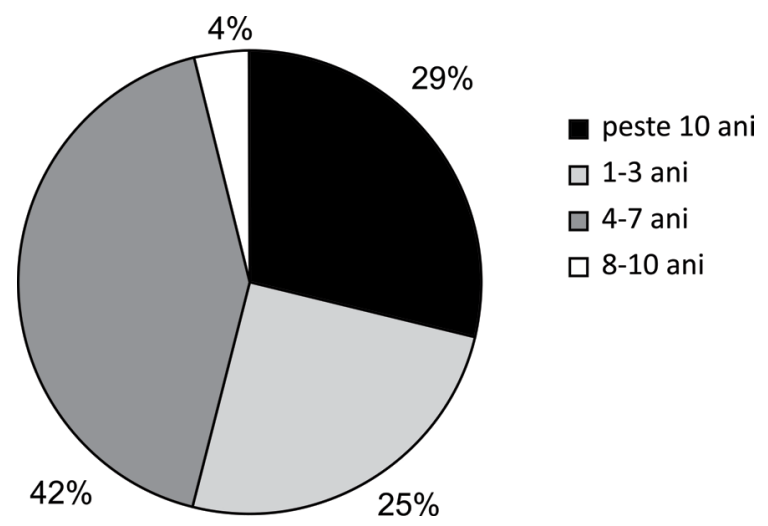

FIGURA 3. Repatiția repondenților pe anii de activitate 
În ceea ce priveşte calificarea, procentul cel mai mic este reprezentat de medicii cu o formă de studii postuniversitare $(17 \%)$, celelalte categorii fiind în procente apropiate, respectiv $29 \%$ medicii cu specializare stomatologie generală, $28 \%$ medicii fără specializare şi 26\% medicii primari (Fig. 4).

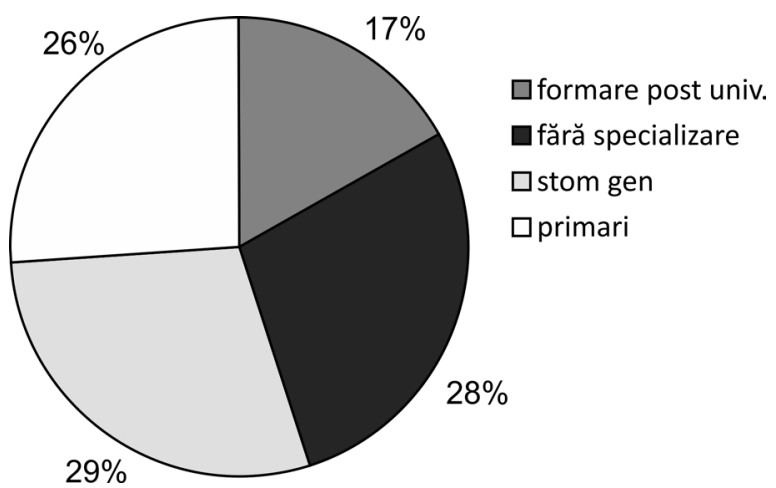

FIGURA 4. Repartiția repondenților după gradul de calificare

Referitor la gradul de solicitare al cabinetului studiul arată că aproape jumătate $(42 \%)$ dintre repondenţi au 31-50 pacienţi pe săptămână şi doar 19\% au peste 50 pacienţi/săptămână (Fig. 5).

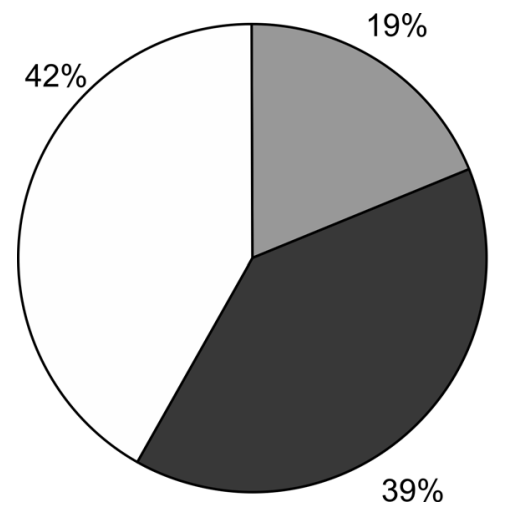

$\square>50$

$\square$ 30-Oct

$\square$ 31-50

FIGURA 5. Repartiție pe grad de ocupare

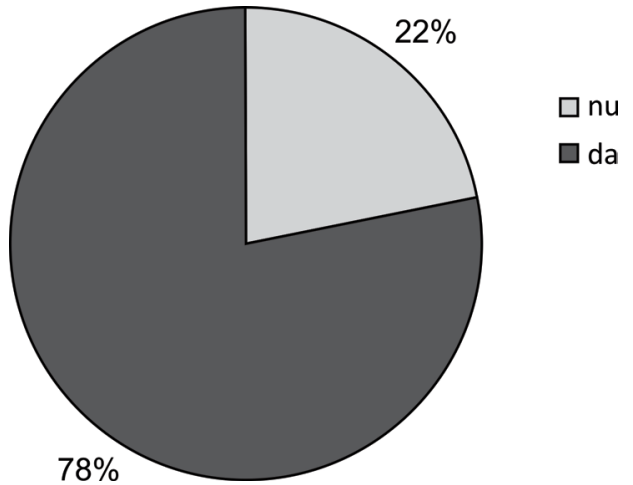

FIGURA 6. Utilizarea TMI

Majoritatea repondenţilor 97 (78\%) cunosc procedurile TMI, dar 28 (22\%) nu le folosesc în practica curentă (Fig. 6).

Dintre cei 97 repondenţi care cunosc TMI, 22 (23\%) le utilizează în activitatea clinică doar ocazional (Fig. 7).

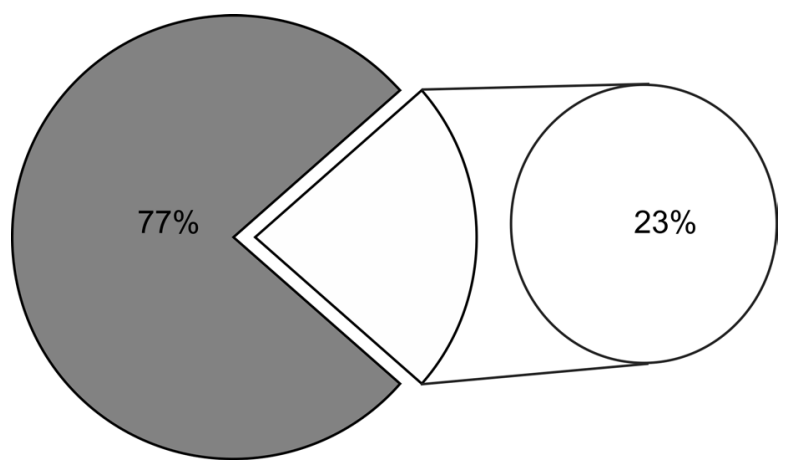

FIGURA 7. Ritmicitatea utilizării TMI

Studiul arată că, la o experienţă profesională de 4-7 ani, tehnicile TMI în tratamentele conservatoare sunt cel mai des folosite $(38,4 \%)$, în timp ce la categoria peste 10 ani acest procent este de doar $12 \%$ (tabel 1). Celelalte două categorii de vârstă analizate au procente asemănătoare, ceea ce denotă o scădere treptată a interesului (Fig. 8).

TABELUL 1. Repartiție experiență profesională şi TMI

\begin{tabular}{|l|c|c|c|c|c|c|c|c|c|c|}
\hline $\begin{array}{l}\text { Experiența } \\
\text { profesională }\end{array}$ & $0-25 \%$ & \multicolumn{2}{|c|}{$25-50 \%$} & \multicolumn{2}{|c|}{$50-75 \%$} & \multicolumn{2}{|c|}{$75-100 \%$} & Total & $\%$ \\
\hline & Val. & $\%$ & Val. & $\%$ & Val. & $\%$ & Val. & $\%$ & & \\
\hline $1-3$ ani & 5 & $4,0 \%$ & 8 & $6,4 \%$ & 10 & $8,0 \%$ & 9 & $7,2 \%$ & 32 & $25,6 \%$ \\
\hline $4-7$ ani & 6 & $4,8 \%$ & 15 & $12,0 \%$ & 12 & $9,6 \%$ & 15 & $12,0 \%$ & 48 & $38,4 \%$ \\
\hline $8-10$ ani & 8 & $6,4 \%$ & 12 & $9,6 \%$ & 6 & $4,8 \%$ & 4 & $3,2 \%$ & 30 & $24,0 \%$ \\
\hline peste 10 ani & 9 & $7,2 \%$ & 3 & $2,4 \%$ & 2 & $1,6 \%$ & 1 & $0,8 \%$ & 15 & $12,0 \%$ \\
\hline
\end{tabular}




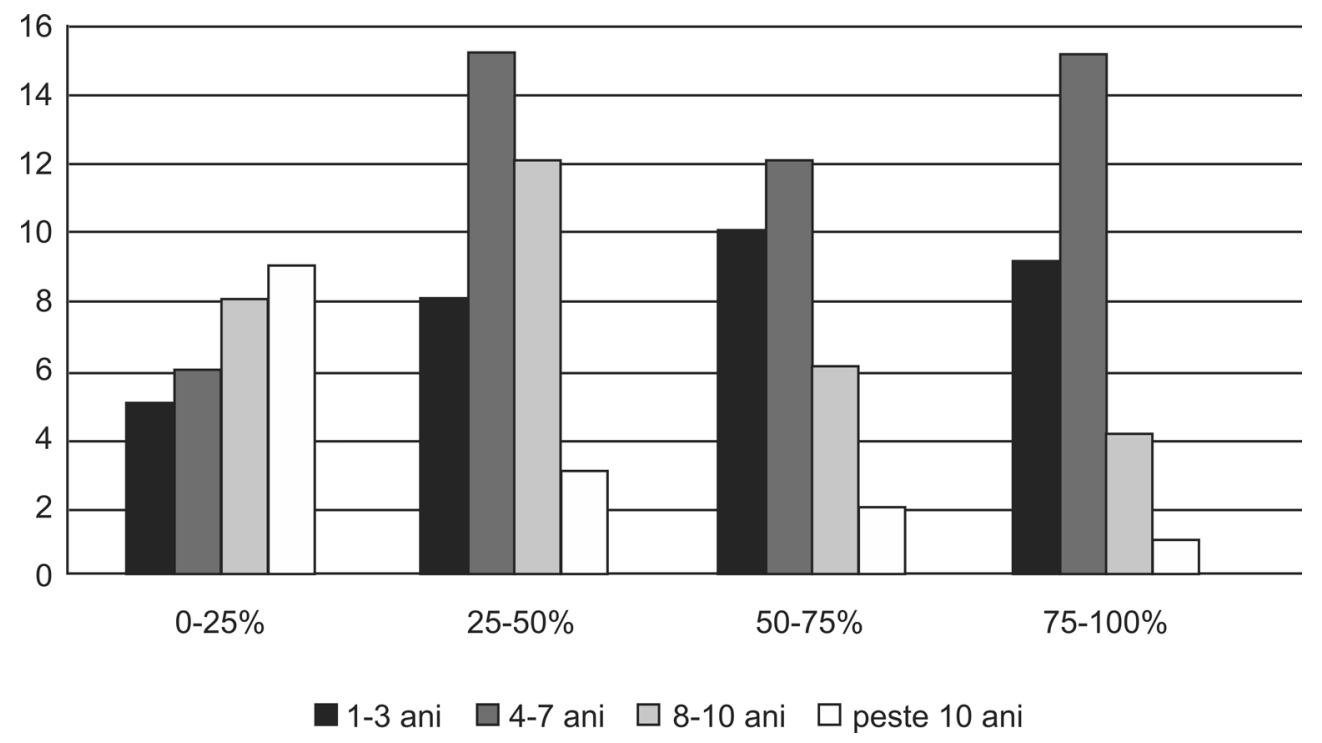

FIGURA 8. Experiența profesională/interes TMI

În ceeace priveşte gradul de pregătire profesională se constată că marea majoritate a repondenţilor acestui chestionar interesaţi de TMI sunt specialişti de medicină generală $(36.8 \%, 46$ repondenti), urmaţi de categoria medicilor fără specialitate (Tabelul 2, Fig. 9). Acest aspect este determinat de rata redusă a absolvenţilor facultăţilor de medicină dentară interesaţi de înscrierea la rezidenţiat dar şi a locurilor nereprezentative rezervate concursurilor de formare.
Pentru a vedea dacă există corelaţie între experienţa practică, gradul profesional şi utilizarea TMI în cabinet, aceste rezultate au fost prelucrate statistic şi s-a calculat coeficientul de corelaţie Spearman (corelaţia Spearman, pe scurt, marcată de simbolul R) care este o măsură nonparametrică a forţei şi a direcţiei de asociere care există între două variabile măsurate la cel puţin o scală ordinală.

TABELUL 2. Repartiție grad profesional şi TMI

\begin{tabular}{|c|c|c|c|c|c|c|c|c|c|c|}
\hline \multirow{2}{*}{ Grad profesional } & \multicolumn{2}{|c|}{$0-25 \%$} & \multicolumn{2}{|c|}{$25-50 \%$} & \multicolumn{2}{|c|}{$50-75 \%$} & \multicolumn{2}{|c|}{$75-100 \%$} & \multirow{2}{*}{ Total } & \multirow{2}{*}{$\%$} \\
\hline & Val. & $\%$ & Val. & $\%$ & Val. & $\%$ & Val. & $\%$ & & \\
\hline Stomat & 11 & $8,8 \%$ & 9 & $7,2 \%$ & 8 & $6,4 \%$ & 4 & $3,2 \%$ & 46 & $36,8 \%$ \\
\hline Primar & 6 & $4,8 \%$ & 7 & $5,6 \%$ & 8 & $6,4 \%$ & 8 & $6,4 \%$ & 31 & $24,8 \%$ \\
\hline Specialist & 8 & $6,4 \%$ & 6 & $5,6 \%$ & 7 & $4,8 \%$ & 3 & $2,4 \%$ & 15 & $12,0 \%$ \\
\hline Fără specialitate & 11 & $8,0 \%$ & 9 & $12,0 \%$ & 8 & $7,2 \%$ & 4 & $4,8 \%$ & 33 & $26,4 \%$ \\
\hline
\end{tabular}




TABELELE 3 şi 4. Corelații experiență şi grad profesional - interes TMI

\begin{tabular}{|l|l|l|l|l|}
\hline Correlations & & & Grad_prof & Interes \\
\hline Spearman's rho & Grad_prof & Correlation Coefficient & 1,000 & $-0,034$ \\
\hline & & Sig. (2-tailed) & & 0,715 \\
\hline & & N & 117 & 117 \\
\hline & Interes & Correlation Coefficient & $-0,034$ & 1,000 \\
\hline & & Sig. (2-tailed) & 0,715 & \\
\hline & & N & 117 & 117 \\
\hline
\end{tabular}

\begin{tabular}{|c|c|c|c|c|}
\hline \multicolumn{5}{|l|}{ Correlations } \\
\hline & & & Experiență & Interes \\
\hline \multirow[t]{6}{*}{ Spearman's rho } & Experiență & Correlation Coefficient & 1,000 &,$- 300^{* *}$ \\
\hline & & Sig. (2-tailed) & & 0,001 \\
\hline & & $\mathrm{N}$ & 125 & 125 \\
\hline & Interes & Correlation Coefficient &,$- 300^{* *}$ & 1,000 \\
\hline & & Sig. (2-tailed) & 0,001 & \\
\hline & & $N$ & 125 & 125 \\
\hline
\end{tabular}

Rezultatele arată că nu există corelaţie între gradul profesional al repondenţilor şi interesul pentru utilizarea TMI, dar există corelaţie între experienţa clinicienilor şi utilizarea acestor manopere. Se poate afirma că fiecare clinician, în urma experienţei profesionale personale, în timp, îşi face o evaluare şi, în acelaşi timp, ierarhizare, a tehnicilor terapeutice şi a materialelor preferate, conform rezultatelor statistice obţinute.

În legătură cu TMI preferate de repondenţi, studiul a arătat că faţetarea directă este tehnica preferată (30\%), iar tunelizarea este cel mai puţin aplicată $(8 \%)$. Faţetarea indirectă este utilizată de $27 \%$ dintre clinicieni, ceea ce reprezintă mai puţin de un sfert din lotul studiat (Fig. 10).

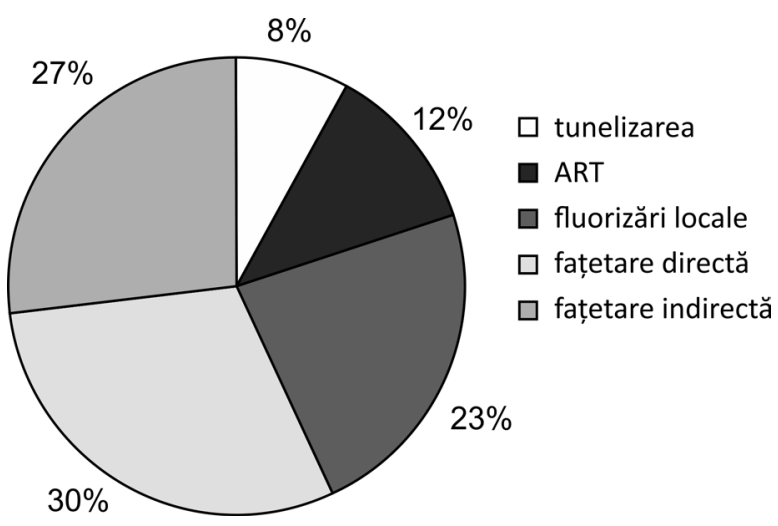

FIGURA 10. TMI utilizate de repondenți

Referitor la patologia pentru care este aplicată tehnica faţetării indirecte, studiul arată că majoritatea repondenţilor $(49,39 \%)$ folosesc tehnica pentru refacerea esteticii, deteriorată de prezenţa tremelor şi diastemei, iar puţin sub un sfert folosesc faţetarea pentru repararea modificărilor de formă şi poziţie dentară. $20(16 \%)$ repondenţi restaurează prin faţetare indirectă discromiile dentare şi un procent egal $(8 \%)$ dintre ei folosesc tehnica pentru demineralizările de smalţ sau modificări ale esteticii (Fig. 11).

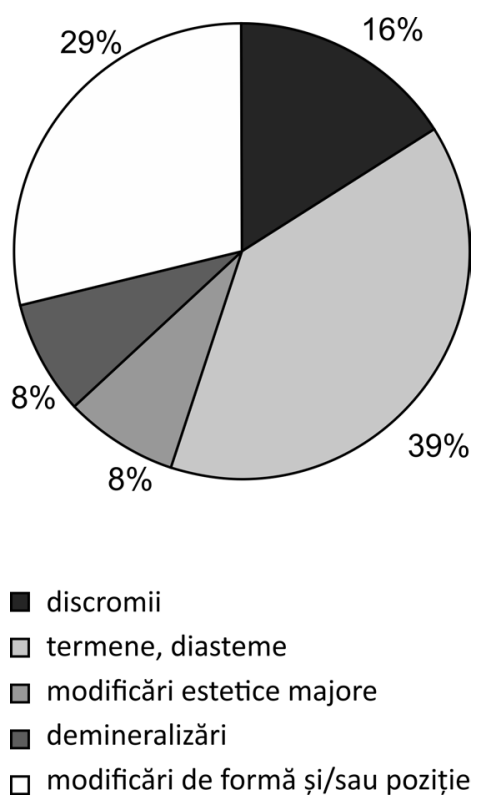

FIGURA 11. Patologia preferată pentru tehnica fațetării

Legat de tehnicile de preparare a dinţilor, opţiunile repondenţilor au fost majoritare pentru design tip fereastră doar la nivelul smalţului (51\%). Preparare vestibulară incizală cu extindere orală este preferată de 32\% dintre repondenţi. 7\% aplică faţete ceramice fără a face niciun fel de preparaţie la nive- 
lul dinţilor şi $10 \%$ utilizează tehnici minimum invazive (ghid de silicon de reducere, utilizarea restaurărilor provizorii). În aceste condiţii se explică de ce peste jumătate dintre repondenţi $(60 \%)$ se rezumă la preparaţie doar la nivelul smalţului, în timp ce doar $11 \%$ se extind până la limita dentinară (Fig.12-13).

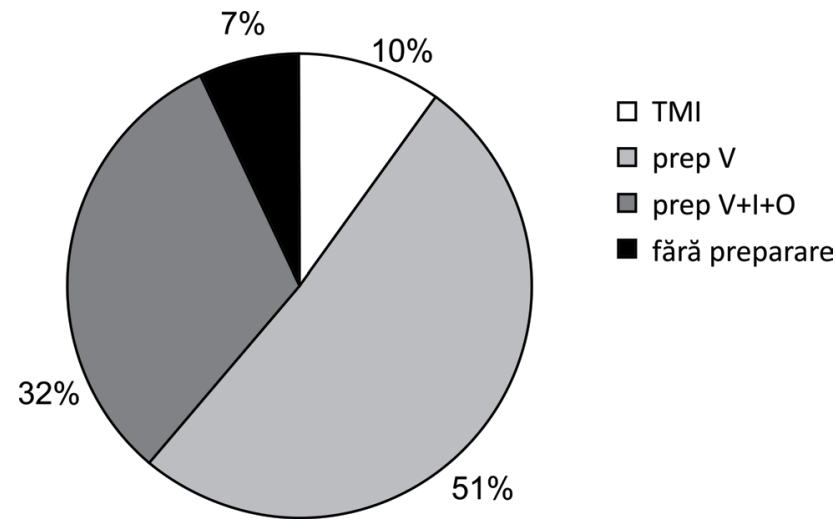

FIGURA 12. Design preparație

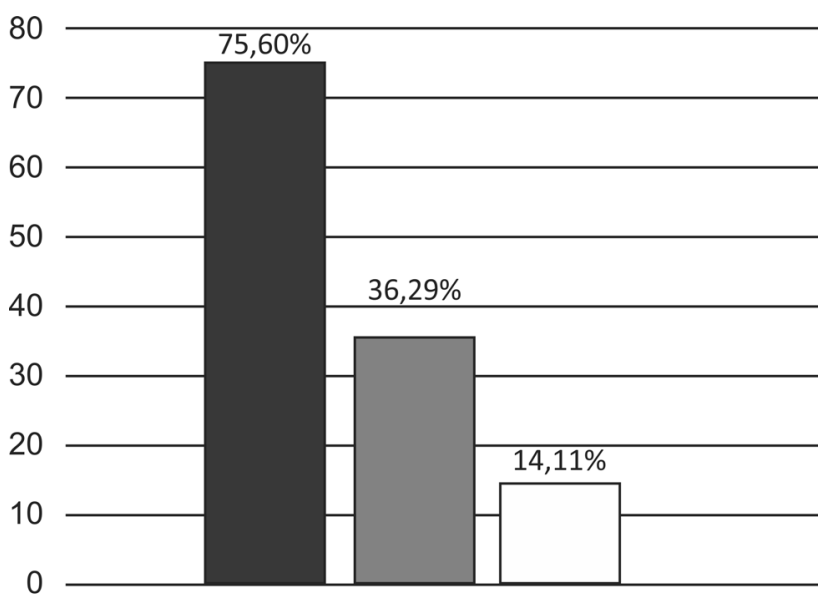

smalț $\square$ smalț-dentină $\square$ dentină

FIGURA 13. Nivel preparare

Pentru a determina în ce măsură experienţa profesională influenţează alegerea modalităţii de şlefuire a dinţilor pentru aplicarea faţetelor indirecte am realizat analiza statistică (Fig. 14, Tabelele 5 şi 6).

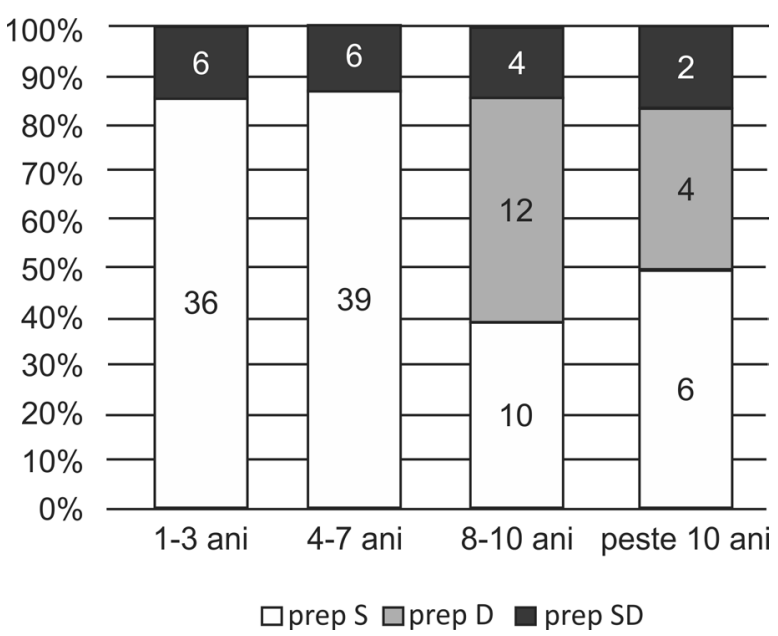

FIGURA 14. Experiența profesională/nivel preparare

TABELUL 6. Corelații experiență profesională - nivel preparare

\begin{tabular}{|c|c|c|c|c|}
\hline \multicolumn{5}{|l|}{ Correlations } \\
\hline & & & Experiență & Tehnici \\
\hline \multirow[t]{6}{*}{$\begin{array}{l}\text { Spearman's } \\
\text { rho }\end{array}$} & Experiență & $\begin{array}{l}\text { Correlation } \\
\text { Coefficient }\end{array}$ & 1,000 & , 314** \\
\hline & & Sig. (2-tailed) & & 0,000 \\
\hline & & $\mathrm{N}$ & 125 & 125 \\
\hline & Tehnici & $\begin{array}{l}\text { Correlation } \\
\text { Coefficient }\end{array}$ &, $314^{* *}$ & 1,000 \\
\hline & & Sig. (2-tailed) & 0,000 & \\
\hline & & $N$ & 125 & 125 \\
\hline
\end{tabular}

S-a constatat existenţa corelaţiei (diferenţei semnificative) între experienţa clinicienilor şi tehnicile de şlefuire a dinţilor utilizate pentru restaurările prin faţetare ceramică.

47\% dintre repondenţi au declarat că folosesc ceramică pe bază de litiu disilicat, în timp ce 19\% lucrează cu zirconiu. Aproape 1/3 din clinicieni au menţionat că folosesc alte ceramici, fără a menţiona consecvent care anume materiale pentru a putea fi luate în consideraţie în studiu (Fig. 15).

Este recunoscut faptul că faţetele au un rol esenţial în îmbunătăţirea esteticii, acest fapt fiind declarat şi de beneficiarii acestui tratament realizat de repondenţii acestui studiu. Aproape 90\% dintre pacienţi s-au declarat satisfăcuti din punct de vedere estetic, $74 \%$ au fost mulţumiţi şi de aspectul funcţionalităţii.

TABELUL 5. Experiența profesională/nivel preparare

\begin{tabular}{|l|c|c|c|c|c|c|c|c|}
\hline Tehnici prep & prepS & $\%$ & prep D & $\%$ & prep SD & $\%$ & total & $\%$ \\
\hline $1-3$ ani & 36 & $28,8 \%$ & 0 & $0,0 \%$ & 6 & $4,8 \%$ & 42 & $33,6 \%$ \\
\hline $4-7$ ani & 39 & $31,2 \%$ & 0 & $0,0 \%$ & 6 & $4,8 \%$ & 45 & $36,0 \%$ \\
\hline $8-10$ ani & 10 & $8,0 \%$ & 12 & $9,6 \%$ & 4 & $3,2 \%$ & 26 & $20,8 \%$ \\
\hline peste 10 ani & 6 & $4,8 \%$ & 4 & $3,2 \%$ & 2 & $1,6 \%$ & 12 & $9,6 \%$ \\
\hline
\end{tabular}


Doar 4\% (5 pacienţi) nu au fost mulţumiţi nici de aspectul estetic, nici de cel funcţional (Fig. 16).

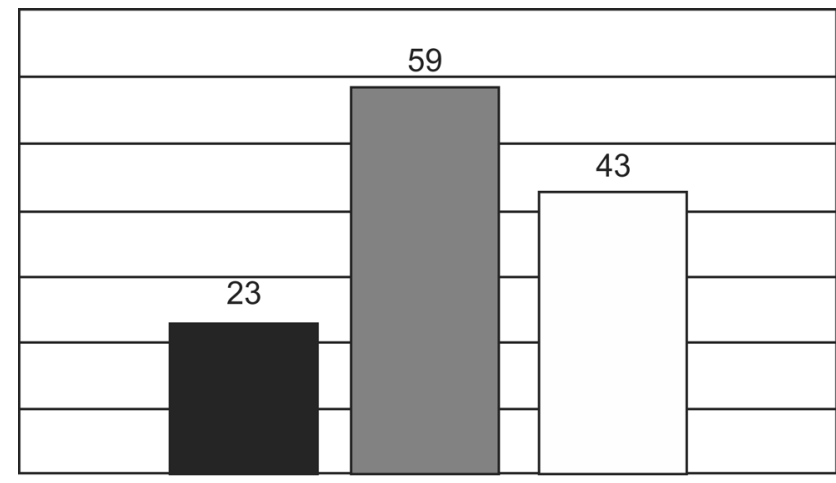

zirconiu $\square$ litiu-disilicat $\square$ alta

FIGURA 15. Tip de ceramică utilizat

TABELUL 7. Repartiție grad satisfacție vs. nivel preparație

\begin{tabular}{|l|c|c|c|c|c|c|c|c|c|c|}
\hline Gr satis. & mulțumit & $\%$ & $\mathrm{f} . \mathrm{m}$ & $\%$ & $\mathrm{fm}$ & $\%$ & $\mathrm{n}$ & $\%$ & total & $\%$ \\
\hline smalt & 30 & $24,0 \%$ & 35 & $28,0 \%$ & 10 & $8,0 \%$ & 0 & $0,0 \%$ & 75 & $60,0 \%$ \\
\hline smalt-dentina & 15 & $12,0 \%$ & 12 & $9,6 \%$ & 9 & $7,2 \%$ & 4 & $3,2 \%$ & 36 & $28,8 \%$ \\
\hline dentina & 4 & $3,2 \%$ & 3 & $2,4 \%$ & 2 & $1,6 \%$ & 5 & $4,0 \%$ & 14 & $11,2 \%$ \\
\hline
\end{tabular}

TABELUL 8. Corelația Spearman

\begin{tabular}{|c|c|c|c|c|}
\hline \multicolumn{5}{|l|}{ Correlations } \\
\hline & & & Material & Satisfăcut \\
\hline \multirow[t]{6}{*}{ Spearman's rho } & Material & Correlation Coefficient & 1,000 &, $214^{*}$ \\
\hline & & Sig. (2-tailed) & & 0,015 \\
\hline & & $N$ & 130 & 130 \\
\hline & Satisfacut & Correlation Coefficient &, $214^{*}$ & 1,000 \\
\hline & & Sig. (2-tailed) & 0,015 & \\
\hline & & $N$ & 130 & 130 \\
\hline
\end{tabular}

TABELUL 9. Repartiție grad satisfacție vs. tip ceramică

\begin{tabular}{|l|c|c|c|c|c|c|c|c|c|c|}
\hline & mulțumit & $\%$ & $\mathrm{fm}$ & $\%$ & $\mathrm{Fm}$ & $\%$ & $\mathrm{~N}$ & $\%$ & total & $\%$ \\
\hline Zirconiu & 14 & $11,2 \%$ & 5 & $4,0 \%$ & 4 & $3,2 \%$ & 0 & $0,0 \%$ & 23 & $18,4 \%$ \\
\hline Litiu-disilicat & 32 & $25,6 \%$ & 22 & $17,6 \%$ & 5 & $4,0 \%$ & 0 & $0,0 \%$ & 59 & $47,2 \%$ \\
\hline Alta & 18 & $14,4 \%$ & 16 & $12,8 \%$ & 5 & $4,0 \%$ & 4 & $3,2 \%$ & 43 & $34,4 \%$ \\
\hline
\end{tabular}

TABELUL 10. Corelația Spearman

\begin{tabular}{|c|c|c|c|c|}
\hline \multicolumn{5}{|l|}{ Correlations } \\
\hline & & & Material2 & Satisfăcut \\
\hline \multirow[t]{6}{*}{ Spearman's rho } & Material2 & Correlation Coefficient & 1,000 & 0,144 \\
\hline & & Sig. (2-tailed) & & 0,105 \\
\hline & & $\mathrm{N}$ & 127 & 127 \\
\hline & Satisfăcut & Correlation Coefficient & 0,144 & 1,000 \\
\hline & & Sig. (2-tailed) & 0,105 & \\
\hline & & $N$ & 127 & 127 \\
\hline
\end{tabular}

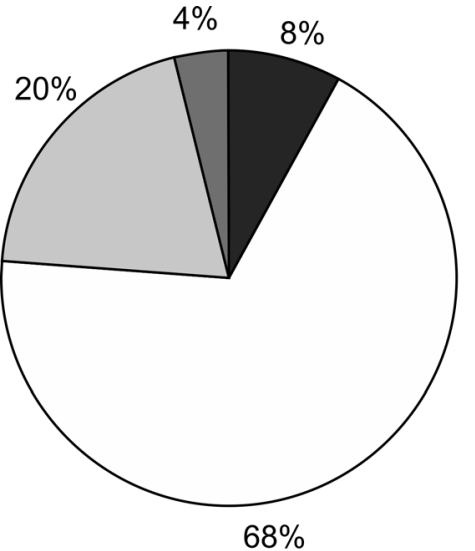

- mulțumit estetic și funcțional

$\square$ foarte mulțumit estetic și funcțional

$\square$ foarte mulțumit estetic

$\square$ nemulțumit estetic și funcțional

FIGURA 16. Repartiția lotului după gradul declarat de satisfactie 
Pentru a determina dacă există corelaţie statistică între gradul de satisfacţie al pacienţilor şi designul preparaţiei sau tipul de ceramică utilizat în realizarea faţetelor dentare, am efectuat analiza statistică (Tabelele 7-10).

Rezultatele au arătat că există corelaţie între gradul de satisfacţie al pacienţilor şi designul preparaţiei $(r=0,015)$, dar nu există corelaţie între tipul de ceramică utilizat şi gradul de satisfacţie al pacienţilor $(r=0,105)$.

Legat de cauzele apariţiei eşecurilor faţetelor vestibulare ceramice, s-a constatat că aproape jumătate $(43 \%) \mathrm{s}$-au decimentat, altele au suferit fisuri sau fracturi (20\%), iar $22 \%$ au pierdut adaptarea marginală (Fig. 17).

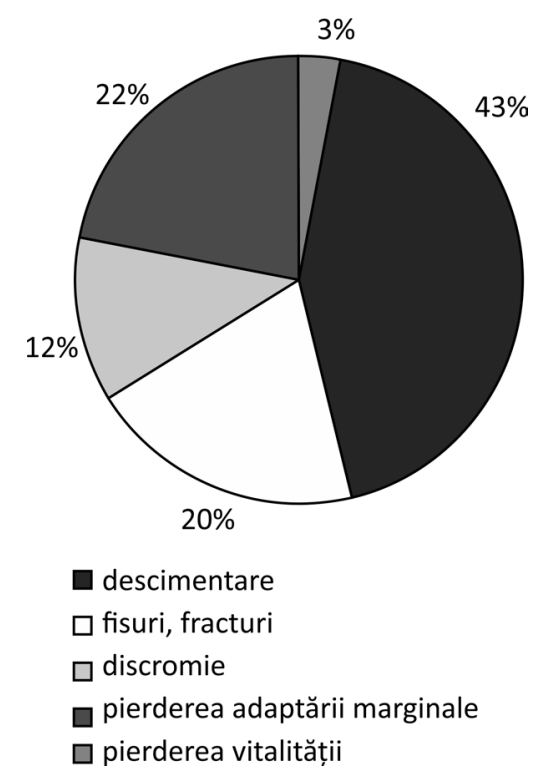

FIGURA 17. Repartiție legată de cauza eşecurilor

Am dorit să determinăm în ce măsură apariţia acestor eşecuri este corelată cu experienţa profesională a clinicienilor repondenţi. Se constată că cel mai afectat grup este cel al repondenţilor cu peste 10 ani experienţă $34,4 \%$ (43 repondenţi), iar categoria 4-7 ani este la extrema opusă, doar 14,4\% (18 repondenţi) au raportat că se confruntă cu aceste eşecuri. Categoriile de grupă 1-3 ani şi 8-10 ani de experienţă profesională prezintă valori raportate ale eşecurilor relativ apropiate, $28,8 \%$ (36 repondenţi) respectiv 22,4 (28 repondenţi) (Fig. 18).

Am folosit testul Spearman pentru a determina corelaţia dintre experienţa profesională a clinicienilor şi apariţia acestor eşecuri (tabelele 11 şi 12).

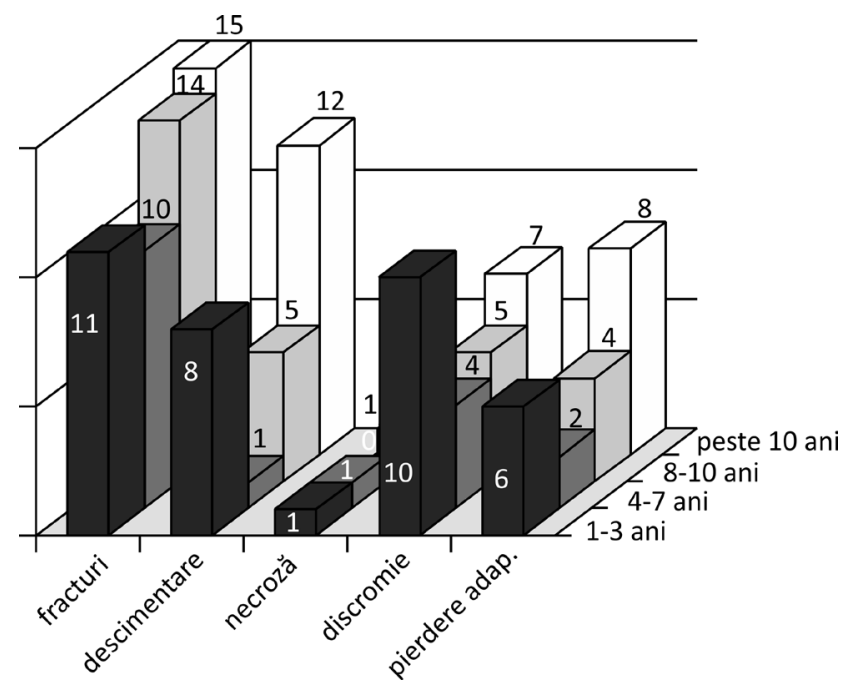

FIGURA 18. Repartiție experiență vs. eşecuri

Rezultatele arată că nu există corelaţie statistică între experienţă profesională a repondenţilor şi eşecurile faţetelor ceramice luate în calcul în acest studiu.

În ceea ce priveşte evaluarea ratei de supravieţuire, 98 (79\%) repondenţi au declarat că aceasta s-ar încadra între 5 şi 10 ani, doar $8 \%$ au evaluat acest item la peste 10 ani (Fig. 19). Dar în mod sigur

TABELUL 11. Repartiția experiență/eşecuri

\begin{tabular}{|c|c|c|c|c|c|c|c|c|c|c|c|c|}
\hline Experienta & fracturi & $\%$ & descimentare & $\%$ & necroză & $\%$ & discromie & $\%$ & pierdere adap & $\%$ & total & $\%$ \\
\hline 1-3 ani & 11 & $8.8 \%$ & 8 & $6.4 \%$ & 1 & $0.8 \%$ & 10 & $8.0 \%$ & 6 & $4.8 \%$ & 36 & $28.8 \%$ \\
\hline 4-7 ani & 10 & $8.0 \%$ & 1 & $0.8 \%$ & 1 & $0.8 \%$ & 4 & $3.2 \%$ & 2 & $1.6 \%$ & 18 & $14.4 \%$ \\
\hline $8-10$ ani & 14 & $11.2 \%$ & 5 & $4.0 \%$ & 0 & $0.0 \%$ & 5 & $4.0 \%$ & 4 & $3.2 \%$ & 28 & $22.4 \%$ \\
\hline peste 10 ani & 15 & $12.0 \%$ & 12 & $9.6 \%$ & 1 & $0.8 \%$ & 7 & $5.6 \%$ & 8 & $6.4 \%$ & 43 & $34.4 \%$ \\
\hline
\end{tabular}

TABELUL 12. Corelația Spearman pentru experiență - eşecuri

\begin{tabular}{|l|l|l|c|c|}
\hline Spearman's rho & Experiență & Correlation Coefficient & 1,000 & $-0,069$ \\
\hline & & Sig. (2-tailed) & & 0,434 \\
\hline & & $\mathrm{N}$ & 131 & 131 \\
\hline & FDDAN & Correlation Coefficient & $-0,069$ & 1,000 \\
\hline & & Sig. (2-tailed) & 0,434 & \\
\hline & & $\mathrm{N}$ & 131 & 131 \\
\hline
\end{tabular}


acest criteriu are un grad ridicat de subiectivism legat de vechimea profesională a clinicienilor, momentul iniţierii în această procedură şi, deci, momentul din care s-a început evaluarea.

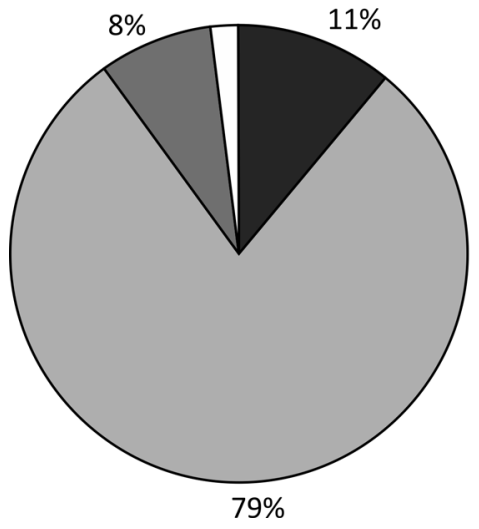

$\square$ 1-3 ani

3-5 ani

$\square$ 5-10 ani

$\square$ peste 10 ani

FIGURA 19. Rată supraviețiire

Pentru a determina gradul de corelaţie între apariţia eşecurilor şi designul preparaţiei, dar şi a tipului de ceramică utilizat, am realizat analiza statistică (Tabelele 13-16).

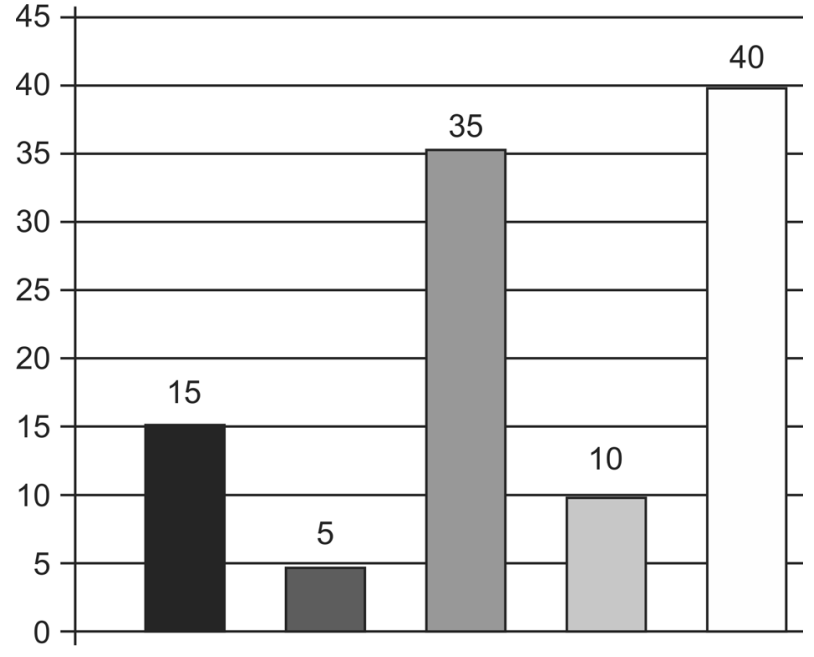

Diagnodent

air abrasion

set preparare faţete

$\square$ instrumente ultrasonice

fără dotare

FIGURA 20. Nivel dotare cabinet

TABELUL 13. Repartiție eşecuri vs tip ceramică

\begin{tabular}{|l|c|c|c|c|c|c|c|c|c|c|c|c|}
\hline & decim & $\%$ & fisuri & $\%$ & discromie & $\%$ & adap & $\%$ & necroza & $\%$ & total & $\%$ \\
\hline Zirconiu & 11 & $8,8 \%$ & 3 & $2,4 \%$ & 4 & $3,2 \%$ & 5 & $4,0 \%$ & 0 & $0,0 \%$ & 23 & $18,4 \%$ \\
\hline Litiu-disilicat & 15 & $12,0 \%$ & 10 & $8,0 \%$ & 18 & $14,4 \%$ & 15 & $12,0 \%$ & 1 & $0,8 \%$ & 59 & $47,2 \%$ \\
\hline Alta & 20 & $16,0 \%$ & 8 & $6,4 \%$ & 6 & $4,8 \%$ & 7 & $5,6 \%$ & 2 & $1,6 \%$ & 43 & $34,4 \%$ \\
\hline
\end{tabular}

TABELUL 14. Corelația Spearman pentru repartiție eşecuri - tip ceramică

\begin{tabular}{|l|l|l|l|l|}
\hline Correlations & & & & \\
\hline & & & Material2 & FDDAN \\
\hline Spearman's rho & Material2 & Correlation Coefficient & 1,000 & -0.066 \\
\hline & & Sig. (2-tailed) & & 0,464 \\
\hline & & N & 125 & 125 \\
\hline & FDDAN & Correlation Coefficient & $-0,066$ & 1,000 \\
\hline & & Sig. (2-tailed) & 0,464 & \\
\hline & & N & 125 & 125 \\
\hline
\end{tabular}

Nu există corelație (diferență semnificativă)

TABELUL 15. Repartiție eşecuri vs. nivel preparație

\begin{tabular}{|l|c|c|c|c|c|c|c|c|c|c|c|c|}
\hline & fract & $\%$ & decim & $\%$ & discro & $\%$ & adap. & $\%$ & necroza & $\%$ & total & $\%$ \\
\hline S & 15 & 12,0 & 25 & 20,0 & 20 & 16,0 & 15 & 12,0 & 0 & 0,0 & 75 & 60,0 \\
\hline SD & 10 & 8,0 & 8 & 6,4 & 6 & 4,8 & 12 & 9,6 & 0 & 0,0 & 36 & 28,8 \\
\hline D & 2 & 1,6 & 0 & 0,0 & 10 & 8,0 & 0 & 0,0 & 2 & 1,6 & 14 & 11,2 \\
\hline
\end{tabular}

TABELUL 16. Corelația Spearman pentru repartiție eşecuri - nivel preparație

\begin{tabular}{|l|l|l|c|c|}
\hline Spearman's rho & Tehnici & Correlation Coefficient & 1,000 & 0,107 \\
\hline & & Sig. (2-tailed) & & 0,230 \\
\hline & & N & 128 & 128 \\
\hline & FDDAN & Correlation Coefficient & 0,107 & 1,000 \\
\hline & & Sig. (2-tailed) & 0,230 & \\
\hline & & N & 128 & 128 \\
\hline
\end{tabular}


Întrucât analiza arată valoarea $\mathrm{r}=0,464$, respectiv, $r=0,230$, nu există corelaţie între apariţia eşecurilor faţetelor ceramice vs. tipul de ceramică utilizat şi nivelul de preparaţie a structurilor dentare.

Legat de dotarea cabinetelor cu aparate şi instumente utilizate în TMI, cei mai mulţi repondenţi, $38 \%$ (40 repondenţi), nu au avut ce raporta la această întrebare, 33\% (35 repondenţi) au în dotarea cabinetului kit de preparare faţete, 14\% (15 repondenţi) au Diagnodent, iar sistemele ultrasonice sau air abrasion sunt în procente mai reduse, 10\% respectiv 5\% (Fig. 20).

\section{DISCUȚII}

Realizarea de sondaje ale medicilor dentişti prin chestionare pe diverse domenii de activitate este o metodă de cercetare utilizată pe scară destul de largă în stomatologie. Acestea se utilizează pentru determinarea nivelului de pregătire profesională, gradul de interes pentru anumite tehnici sau materiale. În orice studiu bazat pe completarea unor chestionare este important să existe reprezentativitatea eşantionului evaluat, adică heterogenitate a eşantionului, cu repondenţi cu pregătire, experienţă, performanţe cât mai variate.

Din cauza solicitării maxime prin materiale comerciale la care sunt supuşi medicii, rata de repondenţi la chestionare profesionale este din ce în ce mai redusă.

Rata de răspuns în acest studiu a fost de 69,4\%, cu procent mai mult decât dublu de răspunsuri ale repondenţilor de sex feminin. Din cei 125 de repondenţi, procentul cel mai mare (37\%) s-a încadrat în grupa de vârstă 26-36 ani, 42\% dintre ei au o experienţă de 4-7 ani şi 29\% au mai mult de 10 ani de la terminarea studiilor, iar în ceea ce priveşte calificarea, procentul cel mai mic este reprezentat de medicii cu o formă de studii postuniversitare (17\%).

Aceste rezultate au fost în acord cu studiul lui Yokoyama Y. et al., care a avut o rată a răspunsurilor de $67 \%$. În schimb, în acest studiu, numărul mediu de ani scurs de la absolvire a fost de 18,5 $\pm 9,9$, iar participanţii au fost predominant bărbaţi (82\%) (1).

Rayapudi J. şi Usha C. au avut în studiul lor o rată de răspuns de 78,8\% la un lot cu aproximativ aceeaşi reprezentare, cu majoritatea reprezentată de medici cu mai mult de 5 ani vechime şi minoritatea formată de medici cu vârsta peste 45 ani (2).
În schimb, alt studiu distribuit online la 793 de dentişti arată o rată de răspuns 55,2\% (3).

Alt studiu recent arata însă o rată a răspunsului de $35,3 \%$ (4).

În ultimele decenii, conceptul de terapie minimum invazivă a fost implementat în diferite domenii ale stomatologiei restaurative $(5,6,7,8)$.

Există însă diferenţe în ceea ce priveşte aplicarea acestor tehnici în practica zilnică (9) deoarece implementarea conceptului minimum invaziv depinde, în afara condiţiilor clinice de aplicare, şi de date demografice sau experienţa şi nivelul de interes al medicilor dentişti $(10,11)$.

Legat de procedurile terapeutice minimum invazive, în studiul meu majoritatea repondenţilor (78\%) cunosc procedurile TMI, dar 22\% nu le folosesc în practica curentă, iar $23 \%$ le utilizeaza doar ocazional.

Alte studii din literatură arată că, în ceea ce priveşte conceptele minimum invazive, majoritatea repondenţilor cunosc acest concept $(82,1 \%)$, dar 49,6\% nu le aplică în practica zilnică (12).

Un chestionar referitor la utilizarea adezivilor dentari de către medicii stomatologi distribuit online la 793 de dentişti, aleşi în mod aleatoriu în zona metropolitană Atena, Grecia, a arătat că o proporţie semnificativă de dentişti $(60,3 \%)$ recomandă utilizarea tehnicilor adezive (3).

În studiul de faţă, aproape $90 \%$ dintre pacienţi s-au declarat satisfăcuţi de restaurările cu faţete ceramice din punct de vedere estetic, iar $74 \%$ au fost mulţumiţi şi de aspectul funcţionalităţii. Doar 4\% (5 pacienţi) nu au fost mulţumiţi nici de aspectul estetic, nici de cel funcţional.

Aceste rezultate sunt în acord cu alte studii care arată că 82,8\% pacienţi au fost mulţumiţi de restaurarea lor prin faţete ceramice (13).

Legat de cauzele eşecurilor faţetelor vestibulare ceramice, în studiul de faţă s-a constatat că aproape jumătate $(43 \%)$ s-au datorat decimentării, altele au suferit fisuri sau fracturi (20\%), iar 22\% au pierdut adaptarea marginală.

Mulţi autori afirmă că fracturile sunt cele mai frecvente cauze ale eşecului clinic al faţetelor ceramice. Astfel, Beier şi colab. arată o rată de eşec a faţetelor ceramice determinată de fractură de 44,83\% în dezacord cu studiul de faţă (14).

O explicaţie a acestui rezultat poate fi dată de procentul ridicat $(60 \%)$ al preparaţiilor strict la nivelul smalţului dentar. 
Discromia, în studiul prezent, este cauza eşecului pentru $12 \%$ dintre faţete, valori diferite de alte studii care arată o decolorare marginală în 21,3\%, $18 \%, 22 \%$ şi $25 \%$ dintre restaurări (15-18).

Apariţia acestor eşecuri este corelată cu experienţa profesională; astfel, cel mai afectat grup este cel al repondenţilor cu peste 10 ani experienţă $34,4 \%$ (43 repondenţi) iar categoria 4-7 ani este la extrema opusă, doar 14,4\% (18 repondenţi) au raportat că se confruntă cu aceste eşecuri, fără a exista însă diferenţe semnificative.

Aceste rezultate sunt in acord cu alte studii care arată că abilităţile clinice insuficiente sau experienţa operatorului au determinat eşecul restaurării (în special schimbările de culoare), care a fost întâlnită la o treime dintre pacienţi (13). În studiul de faţă nu există diferenţă semnificativă între apariţia eşecurilor faţetelor ceramice şi tipul de ceramică utilizat sau nivelul de preparaţie a structurilor dentare.

Acest aspect este în dezacord cu studiul lui Saeed Al-Dolaie IM şi colab., care arată că tipul de ceramică a avut un efect semnificativ asupra rezistenţei faţetelor confecţionate din litiu disilicat ranforsat cu zirconiu comparativ cu cele realizate din litiu disilicat. În studiul lor, cel mai frecvent tip de eşec a fost eşecul mixt, determinat de fractura dentară, fractura faţetă, decimentare (19).

Şlefuirea smalţului afectează în mod negativ distribuţia stresului, ceea ce duce la o creştere a flexiei şi, în cele din urmă, la o fractură coezivă (20).

\section{CONCLUZII}

Tehnicile minimum invazive, cu referire specială la faţetarea vestibulară ceramică, reprezintă proceduri din ce în ce mai utilizate în cabinetele dentare. Realizarea unor analize diagnostice corecte asociate cu experienţa operatorului şi respectarea unui protocol terapeutic strict pot determina creşterea ratei de supravieţuire a faţetelor realizate din materiale ceramice.

\section{Menţiune}

Toţi autorii au contribuţie egală în realizarea acestui articol.

\section{BIBLIOGRAFIE}

1. Yokoyama $Y$ et al. Dentists' practice patterns regarding caries prevention: results from a dental practice-based research network Dentistry and oral medicine. BMJ Open 2013;3:e003227.

2. Rayapudi J, Usha C. Knowledge, attitude and skills of dental practitioners of Puducherry on minimally invasive dentistry concepts: A questionnaire survey. J Conserv Dent. 2018 May-Jun; 21(3): 257-262.

3. Polyzois $\mathrm{G}$ et al. Attitudes of dentists toward denture adhesives: $\mathrm{A}$ questionnaire survey in Greece. The Journal of Prosthetic Dentistry. November 2017 Volume 118, Issue 5, Pages 643-649

4. Kanzow P et al. Repair restorations: Questionnaire survey among dentists in the Canton of Zurich, Switzerland. 2017, Swiss Dental Journal, 127(4):300-311

5. Vidnes-Kopperud S, Tveit A B, Espelid I. Changes in the treatment concept for approximal caries from 1983 to 2009 in Norway. Caries Res 45: 113-120 (2011)

6. Doméjean S, Léger S, Maltrait M, Espelid I, Tveit A B, Tubert-Jeannin $\mathrm{S}$. Changes in occlusal caries lesion management in France from 2002 to 2012: A persistent gap between evidence and clinical practice. Caries Res 49: 408-416 (2015) Fernández E, Martín J, Vildósola P, Oliveira

7. Frankenberger R, Vosen V, Krech M, Krämer N, Braun A, Roggendorf MJ. Darf's ein bisschen weniger sein? Quintessenz 65: 541-545 (2014)

8. Oliveira DC, Warren JJ, Levy SM, Kolker J, Qian F, Carey C. Acceptance of minimally invasive dentistry among US dentists in Public Health Practices. Oral Health Prev Dent 14: 501-508 (2016)

9. Schwendicke $\mathrm{F}$ et al. Managing Carious Lesions: Consensus Recommendations on Carious Tissue Removal. Adv Dent Res. 2016 May;28(2):58-67.

10. Alani A, Bishop K, Djemal S. The influence of specialty training, experience, discussion and reflection on decision making in modern restorative treatment planning. Br Dent J 210: E4 (2011)

11. Gordan VV, Riley J 3rd, Geraldeli S, Williams O D, Spoto J C 3rd, Gilbert G H. National Dental PCG: The decision to repair or replace a defective restoration is affected by who placed the original restoration: Findings from the National Dental PBRN. J Dent 42: 1528-1534 (2014)

12. Katz CR, de Andrade Mdo R, Lira SS, Ramos Vieira EL, Heimer MV. The concepts of minimally invasive dentistry and its impact on clinical practice: A survey with a group of Brazilian professionals. Int Dent $J$. 2013 Apr;63(2):85-90.

13. Diemah F. Alhekeir et al. Porcelain laminate veneers: Clinical survey for evaluation of failure. Saudi Dent J. 2014 Apr; 26(2): 63-67.

14. Beier US et al. Clinical Performance of Porcelain Laminate Veneers for Up to 20 Years. Int J Prosthodont 2012;25:79-85.

15. Beier US et al. Clinical Performance of Porcelain Laminate Veneers for Up to 20 Years. Int J Prosthodont 2012;25:79-85.

16. Dumfahrt $H$, Schäffer $H$. Porcelain laminate veneers. A retrospective evaluation after 1 to 10 years of service: Part II-Clinical results. Int J Prosthodont 2000;13:9-18.

17. Christensen GJ, Christensen RP. Clinical observations of porcelain veneers: A three-year report. J Esthet Dent 1991;3:174-179. 35.

18. Jaeger K, Stren M, Wirz J. Laminates-Reif fuer die Praxis? Die Quintessenz 1995;46:1221-1230.

19. Saeed AI-Dolaie IM et al. Failure of porcelain laminated veneer using two different materials. JODR Volume 4, Issue 2, 2017

20. Alavi AA., Behroozi Z., Nik Eghbal F. 2017. The Shear Bond Strength of Porcelain Laminate to Prepared and Unprepared Anterior Teeth. J Dent Shiraz Univ Med Sci. (1): 50-55. 